\title{
Macedonians of Islamic Religion in the Context of Identity Theories
}

\author{
Katica Kulavkova, Academician, Ph.D. \\ Macedonian Academy of Sciences and Arts (MASA), \\ Republic of Macedonia
}

Doi:10.19044/esj.2018.v14n17p105 URL:http://dx.doi.org/10.19044/esj.2018.v14n17p105

\begin{abstract}
In line with the theories of variability, fluctuation and instability of ethno-cultural identities, this paper deals with some sensitive issues surrounding the creation of new (sub-ethnic and sub-cultural) microidentities within one nation, in this case within the Macedonian nation.

The research focuses on the initiative for declaring one part of the Macedonian nation, the Macedonians of Islamic religion, to be a separate ethnic group in 2011. It analyses the regional and historical background from which this initiative originated, mostly as an echo of the multicultural strategies and policies in the European and international context. It shows how the unstable politics destabilized the already fragile and fluctuating identity of this group toward an identity of resistance or even heresy, inspite of having preserved their primary Slavic linguistic and cultural identity.

The paper argues that the Macedonians of Islamic religion are a part of the Macedonian social, cultural and religious reality and should therefore be recognized as a specific cultural-religious community within the Macedonian national entity. This issue is seen as very important in the present context, since the Macedonian identity is preasured and relativized itself. The paper underlines that the Macedonian national identity is inclusive, layered, more general and complex than its religious factor. Therefore this researcher proposes inclusive state policies for all Macedonians regardless of religious affiliation, inclusive civilizational strategies with inter-connective spiritual values (inter-religious palimpsests and symbiosis) and inclusive state secular strategies as protection against religious radicalisms, atavisms and conflicts.
\end{abstract}

Keywords: (Slavic) Macedonians, Macedonians of Islamic religion (Macedonian Muslims, Torbeshi), sub-cultural micro-identity, fluctuating identity, identity of resistance 


\section{Introduction}

\section{The dominant factors of the Macedonian identity as ethnicity and as citizenship}

Nation and religion in modern times are not contradictory conceptions, but they are not corresponding in full either. Religious identity (confession) used to be the main determining factor in some previous times when the ethnic identity originated from the religious one, especially in the Ottoman Empire under the "millet" system". In the Macedonian case, throughout (recent) history the determining identity factors were (mostly) linguistic and religious affiliation. ${ }^{12}$ The Macedonian language belongs to the family of South Slavic languages. ${ }^{13}$ By religion, Macedonians today are mainly Orthodox Christians ${ }^{14}$ and partly Muslims, but in prechristian times

${ }^{11}$ The millet system in the Ottoman Empire was based on the ethno-religious identification of the non-Muslim Ottoman communities (minorities). The following millets were established in the Ottoman Empire: the Muslim millet, the Rum(elia) millet or East Orthodox millet, the Frankish (Roman Catholic) millet, the Armenian-Gregorian millet (from which the Syriac Christian millets were later separated) and the Jewish millet. This was a multi-millet system, explicitly multi-religious, implicitly multiethnic and multilingual. For more on the Ottoman millet system in regard to Macedonia see the chapter „Group Identity in the Ottoman Empire: From Millet to Nation" (Poulton, 2000, pp. 26-47).

12 In the absence of stable national/state institutions, but with a persistant presence of propagandistic, colonial and denationalizing strategies and policies, the Macedonian people protected the language as their basic cultural identity characteristic. The language was a space for memorizing, recollection, feeling, communication, cognition, lore, creation, mystification, fantasizing, performing religious rites, bestowing benediction, prophesying, healing, deification, legalization, making sense of existence and of one's own image, its genus. In one word, the Macedonian language had grown into the territory or home of identity. That is why the emphatic sensitivity regarding the language is so essential and inviolable to this day. In addition, the language of the so-called Macedonian Slavs (or Slavic Macedonians) is spoken on a geographical territory analogous to the the geographical territory of Macedonia in a way that the language becomes synonymous with the Macedonian ethno-cultural identity. For the development of the Macedonian linguistic identity from an integral linguistic perspective, but with explanations on the geographical and sociopolitical aspects, see Victor A. Friedman's essays "The Sociolinguistics of Literary Macedonian" and "Language in Macedonia as an Identity Construction Site" in his book Macedonian Studies 2 (2015, pp. 185-212, 285-318).

${ }^{13}$ The South Slavic languages are the southern branch of the Slavic languages (languages of the Slavic peoples), which descend from the Balto-Slavic group of the Indo-Eropean family of languages. The South Slavic languages are spoken by approximately around 30 million speakers mainly in the Balkans, and the Macedonian language belongs to the Eastern group of the South Slavic languages. The Macedonian language is also classified as a part of the Balkan linguistic league (Balkan Slavic \& Non-Slavic language group based on contact linguistics, Sprachbund vs. Sprachfamilie), see Victor A. Friedman (2017). See also the online resources on the Macedonian language in the General Slavic Linguistic Atlas (OLA, 2018), the Research Centre for Areal Linguistics of the Macedonian Academy for Arts and Sciences (2018a) and its Digital Archive of the Macedonian Language (2018c).

${ }^{14}$ Throughout the centuries the Macedonian Orthodox Church Ohrid Archbishopric had a 
their confession was polytheistic (pagan). These factors were supplemented by other, ethnogenetic, ethnographic, ethnocultural and social characteristics of the Macedonians: popular culture, oral tradition, script usage tradition (Greek, Latin, Glagolitic, Cyrillic script), collective memory, territorial scope and institutional (state) constellation in which they lived and expressed themselves (propagandas, conversions, migrations, politics). ${ }^{15}$

Today, in the Republic of Macedonia the Macedonian language still remains an essential factor of the Macedonian identity, but the constellation in which this factor acts became complicated. On one hand, there is an attempt to constitute the Macedonian nation as a supra-ethnic category, whereupon the Macedonian language would be a language of official and public communication for all citizens independently of ethnic origin. On the other hand, with the establishment of the "multiethnic democracy" and multilingualism, the Macedonian language is increasingly linked to the ethnic frameworks. Moreover, specific parts of the Macedonian nation are put under pressure to convert on linguistic, religious and ethnic basis (Cowan, 2000).

When talking about the religious factor, these days the policies for disintegration of the Macedonian nation on the religious principle are so intensified that they are even influencing policies for disintegration of the Macedonian ethnicity itself. Thereby, there is a type of intra-Macedonian "millet system" of Macedonian confessional identities: Macedonian Orthodox Christians, Macedonian Muslims, Macedonian Catholics, Macedonian Protestants (Methodists, Evangelists, Adventists, Jehovah's Witnesses and other). On top of that, in the national structure of the Macedonian nation there is a whole spectrum of small confessional-ethnic communities and religious groups (an intensive fragmentation on both ethnic and religious principle): Albanian Muslim and Albanian Christian (Catholic, Orthodox) community, Turkish Muslim community, Bosnian Muslim community, Romani Muslim community, Jewish religious and ethnic

great role in developing, representing and conserving the Slavic Macedonian Orthodox Christian culture. The Old Church Slavonic (the first documented literary pan-Slavic language and official lithurgic language c.850-1100 AD like Latin was for the Catholic Church) was created on the basis of the Macedonian South Slavic dialect of the Old Slavic vernacular spoken in the Bysantine Province of Thessalonica (Krause \& Slocum, 2003). After $1100 \mathrm{AD}$, the Church Slavonic language of the Macedonian recension was kept to this day in Macedonia (Ribarova, 2000, 2005).

${ }^{15}$ Research shows that the names of the ancestors of the Islamised Macedonian population were Slavic. See: Krasimira Koleva (2014), Maksim M. Makarcev (2014), Muhamed Arslani (2011), Veselka Toncheva $(2014 ; 2016)$ and Rigels Halili (2013). Toncheva writes about the „Slavic-speaking community“ in the region Golo Brdo (Albania) and their ethnomusical heritage. 
community $^{16}$, Aromanian Christian community, Serbian Orthodox Christian community... ${ }^{17}$

It should be emphasized here that there is a distinction between the linguistic factor and the religious factor in the Republic of Macedonia. Within the Macedonian language community there are several confessional (i.e. religious-cultural) communities, but the linguistic community is a more general category than the religious-cultural. The Macedonian nation implies many linguistic and religious communities. In traditional sense of the word, the Macedonian nation is composed of several ethno-cultural and religiouscultural communities. It seems that in time the religious identity, the confessional traditions and the religious ethical code generate specific subcultural formations. Today they represent the wealth of the Macedonian nation. Yet, it seems that language and religion have transformed into divisive, disintegrative factosr (rather than unifying, integrative factors) for the separate ethnic communities and groups within this nation with a transethnic, civil and civilizational identity. Moreover, the mere concept of this nations's national identity is relativized because its traditional dominant and constructive identity factors are minimized and marginalized. Today we can speak more about the dominant factors of disidentification of this nation than about the factors of its identification.

The Balkans is a palimpsest of millennial sedimentary identity traditions, so it is not easy to erase the old "records of culture". Therefore, a distinction should be made between the explicit manifestation of identity and the implicit survival of identity, whereby we are thinking of the collective identities with an ethnic, religious, linguistic and cultural dominant. Citizenship is still felt as an additional mark, more administrative than essential, so a part of the Macedonians is reserved and distant toward such civil or national identity. But not when it comes to the Macedonian ethnocultural identity (ethno-genesis, language, cultural traditions, customs, collective memory). It should be taken into account that, despite the attempts for resemantization of the concept of Macedonians, there still exists an

\footnotetext{
${ }^{16}$ See Jolanta Sujecka (2012).

${ }^{17}$ One should note here that the Republic of Macedonia is a small state with surface area of $25.713 \mathrm{~km}^{2}$ and population of 2,073.702 at the end of 2016 according to population estimates (State Statistical Office, 2017, p. 9). But, the estimates of the number of various groups is not available (including the number of the Macedonians of Islamic religion), since the country has not held a census since 2002 (and previously in 1997) due to political frictions centered around the legal rights of minorities after the 2001 Ohrid agreement to elevate any minority language into a co-official language for that municipality if the minority in question is above $20 \%$ of the population of that municipality. Available census data (State Statistical Office, 2002) is comprehensively analalysed in regard to the contesting identity categories of mother language, nationality and religion by Victor A. Friedman (2015, pp. 308-318).
} 
identifiable substrate that regenerates the consciousness of ethnic distinctiveness and stimulates the urge for its protection. Especially in conditions when there are imposed factors that obstruct its free and unconditional self-determination and recognition at both regional and international level and in regional and international institutions.

In this general context, the Macedonians of Islamic religion belong to the Macedonian linguistic community. ${ }^{18}$ The dominant stereotype about them is that they speak the purest Macedonian language with the least amount of barbarisms and internationalisms. Yet, on a cultural level they form their own (sub-cultural) matrix marked by the Islamic theosophy, ethics and worldview (the Quran and its idiom), as well as by the Islamic ritual practices. However, even in those conditions, the ethnologists, ethnographers, folklorists and anthropologists prove that there is a mutual Macedonian ethno-cultural substrate that all the Macedonians share, even those who practice the Islam (Bozhidar Vidoevski, 1998; Aneta Svetieva, 1992, 2004; Mirjana P. Mirchevska, 2007, 2011, 2014; A. A. Plotnikova, M. Ju. Martinova and E. S. Uzeneva, eds., 2014).

Concurring with the above, Mario Sharevski in his study "Geographical Distribution and Ethnographic Characteristics of the Macedonian Muslims in the Republic of Macedonia" (2015) explains the following: "In the ethnographic characteristics of the Macedonian Muslims in the Republic of Macedonia there are two clear tendencies and indicators. In regard to their geographical distribution they have the same ethographic characteristics and ethnologic features in language and speech and in customs and habbits as the ones of the Macedonian Christians living in the given areas and regions, which clearly points toward their ethnic affiliation as a part of the Macedonian people. On the other hand, the different kinds of processes of receiving the Islam and the various social and political status the Macedonians of Islamic religion used to have, all influenced the occurence of different self-determinations, national sentiments and orientations. Thereby, the Macedonians of Islamic religion in Dolna Reka area in the Reka region and also in the Debar region (as far as Golo Brdo) distinguish themselves by a particular Macedonian national awareness and determination, while the Macedonians of Islamic religion from the Struga area have a distiguished awareness and determination as "Torbeshi" and partly as Albanians, Turks and Macedonians. Then, in the Kichevo region, in

\footnotetext{
${ }^{18}$ The last two-three decades (after the breakup of SFR Yugoslavia) show deviations from this rule, whereupon the Macedonians of Islamic religion are educated in Turkish or Albanian languages, which successively affects their conscience about ethnic affiliation and self-determination. This is a consequence of the unstable social, political and economic conditions in the Republic of Macedonia, including the revisions of the Constitution and the laws.
} 
the Zhupa area of the Debar region, in the Torbeshi area of the Skopje region and in the Pelagonia region the Macedonians of Islamic religion almost entirely (with only slight exemptions) determine their nationality as Turkish. This occurance in the various self-determination of the Macedonians with Islamic religion has negative influence by setting these citizens as targets for various political manipulations and preasures."

For a better understanding of the geographical dispersion of this population in the Republic of Macedonia and in the neighbouring region, the researcher includes this map, based on Sharevski's research ${ }^{19}$ :

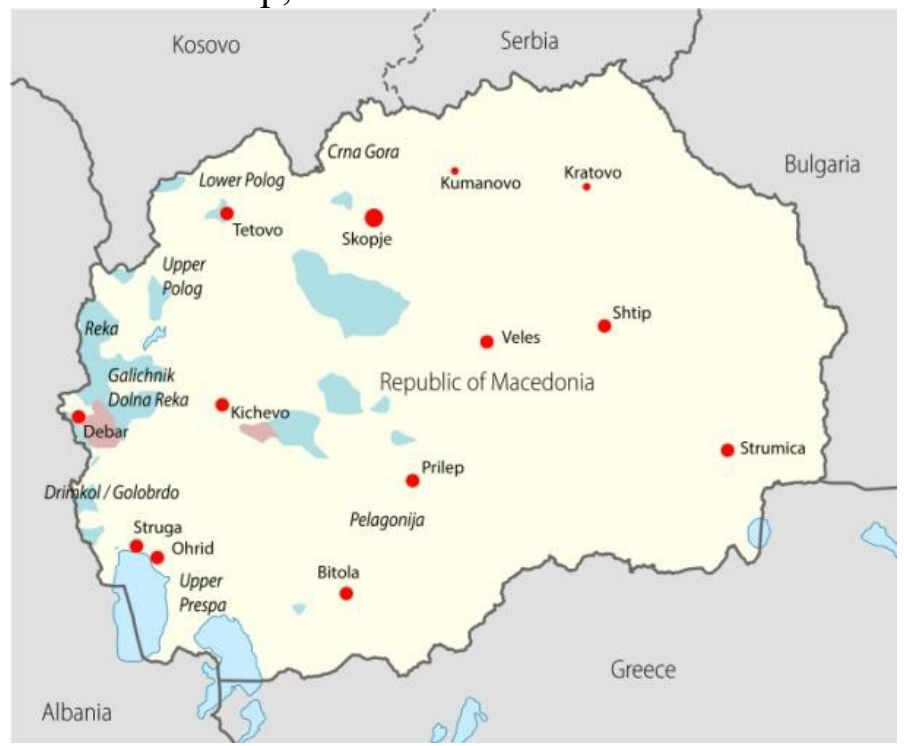

Map 1. Geographical dispersion of Macedonians of Islamic religion in the Republic of Macedonia

Areas where Macedonians of Islamic religion are concentrated

Areas where Macedonians of Islamic religion make up a majority population

In 1991 the father of Macedonian dialectology Bozhidar Vidoeski wrote a meticulous paper on the dialectal characteristics of the language of

19 "In regard to geographical dispersion, Macedonian Muslims are dispersed almost on the entire territory of the Republic of Macedonia with a particular compactness and concentration in western Macedonia. Namely, from the area of Drimkol and Malesija in the west to the Struga region in the south, across the Debar and Reka region in the north and parallel with the western Macedonian border with Albania there is a complete zone and an uninterrupted belt of settlements with Macedonians of Islamic religion. Their number in this part is so large that they represent the majority group in the regions of Debar and Reka, also in the regions of Struga and Kichevo. Together with the Macedonian Orthodox population in these parts they create the majority Macedonian ethnic element. [...] Smaller groups of Macedonians with Islamic religion live on the same meridian lineal dispersion from north to south in the middle part of the Republic of Macedonia - in the regions of Skopje, Veles and Pelagonia." (Sharevski, 2015) 
the Macedonians of Islamic religion in comparison with the language of the Macedonians of Orthodox Christian religion living in same areas „The Dialects of the Islamized Macedonians in Western Macedonia" (1998, p. 309-339). In this paper there is an overview of all the small vilages and settlements with Macedonian Muslim population and an extensive elaboration on the dialectal specifics of those dialects. His study shows that the language of the Macedonian Muslim population is synchronically and diachronically identical to the language of the Macedonian Orthodox Christian population in the same or in the neighbouring settlements (since some of the groups migrated from nearby areas with a slightly different Macedonian dialect). The dialects of both groups are geneticly connected and they entirely share all the main features of the Western corpus of Macedonian dialects. The only "small differences can be found in the frequency of use of a certain number of lexems with Turkish origin from the customary and religious nomenclature, which neither disrupts the phonological composition, nor the grammatical structure of the given dialect" (p. 338). Furthermore his research shows that the mixed populations which migrated from areas with different Macedonian dialects created new, inovative, original dialectal features. Here is the map of Western Macedonia with the (Slavic) Macedonian dialects spoken by the Macedonians of Islamic religion that he included in his study:

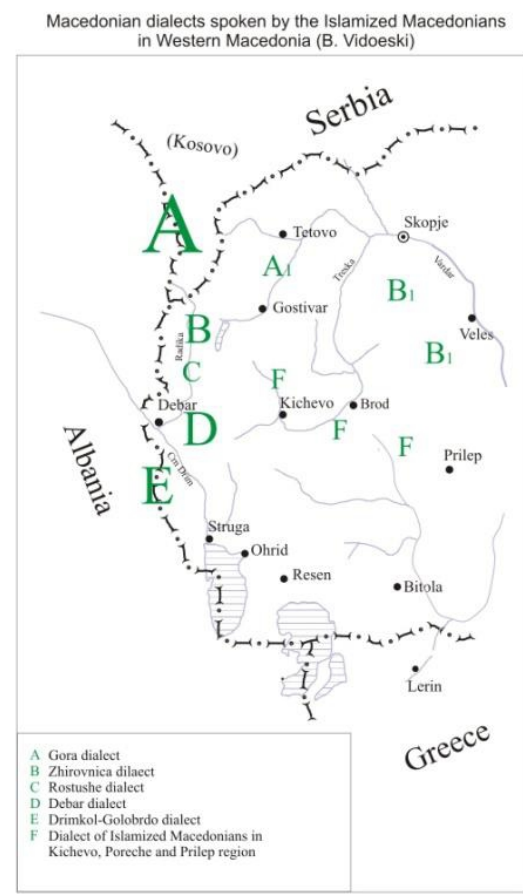

Map 2. Macedonian dialects spoken by the Macedonians of Islamic religion in Western Macedonia (B. Vidoevski) 


\section{Autochthony as a problematic factor}

Autochthony as a factor of determining one's ethnic identity should be accepted with certain reserve, since it can be over-mythologized and overpoliticized, especially in the Balkans and especially in times of recomposition of state and national borders and of re-distribution of the political and economic power among the ruling circles. The more one tries to support the current, contemporary position of one nation with the help of the factor of antiquity and autochthony, the more one is exposed to an absence of material proof, faced with the so-called dark periods of history. In other words, the deeper one enters in the history of a nation, especially of bordering nations, the higher the risk of identity delusions, identity manipulation and wrong, partial and tendentious interpretation of ethnic identities. In fact, the emphasis on autochthony as a primary factor in determining identity leads to adoptive, assimilating and conquering policies.

In the beginning of the $21^{\text {st }}$ century in the Republic of Macedonia and in the wider Balkan region, there was a re-establishment of the $19^{\text {th }}$ century propagandas and strategies for ethnic, religious, linguistic and even civil (citizenship) conversion. We have even reached a situation in which the theory of variability, fluctuation and instability of ethno-cultural (ethnolinguistic) identities has become a generator of new micro-identities, new sub-ethnic and sub-cultural identities within one nation, in this case within the Macedonian nation. ${ }^{20}$ The new factor of individual and group/collective self-determination entered the social (and theoretical) scene and transformed from an optimal civil option (the human right to free self-determination and self-identification) to a factor that stimulates the creation of some imaginary or "imagined" communities (Anderson, 1998, 2006) ${ }^{21}$. This reflected on the status of the Macedonians of Islamic religion, especially in regard to their right of self-declaration and self-identification, as well as in regard to their integration in the Macedonian nation (Bart, 2007).

New ethnicities and "parts of nations" (which is a constitutional category in the Republic of Macedonia since 2001) started to be created and

\footnotetext{
${ }^{20}$ See how Montserrat Guibernau (2004) revises Anthony D. Smith's classical definition of nation, state and national identity in the 21 st century. He explains the need for redefining and separating these categories in the global era, he proposes new, flexible and dynamic definitions and he introduces categories like "nation-state" and "nation without a state", also having in mind the phenomena of multiple national identities and of different/other national identities which are in opposition to the national identity promoted by the state and viewed separately from citizenship.

21 Political scientist and historian Benedict Anderson in his 1983 study of nationalism Imagined communities defined the term nation in the following manner: "in an anthropological spirit, then, 1 propose the following definition of the nation: it is an imagined political community - and imagined as both inherently limited and sovereign" (2006, pp. 5-7).
} 
declared by declarations and constitutionally in the Republic of Macedonia, a state stratified on all grounds (ethnic, religious, linguistic, territorial, political and institutional). In social life, in politics and in the institutions some small, relatively isolated, "imaginary" ethno-religious communities that are subject to strong lateral (political and economic) influences started to separate their identity. Such communities are based, mainly, on unsubstantiated historical argumentations and biased auto-perceptions, thus manifesting some elements of ethno-nationalism, as well.

In this context the identification and self-identification of the Macedonians of Islamic religion became even more complicated. There is a not so quiet, internal differentiation of this religious community (which is here designated with the term "Macedonians of Islamic religion" with certain reserve). Namely, (1) one part of this Macedonian population is declaring its identity as Macedonian, but of Islamic religion, (2) the second part is declaring itself as a specific, autonomous and autochthonous identity that is recognized by the name "Torbeshi", and (3) the third part promotes complete integration with the Macedonian people and nation and is against separate identification of the Macedonians on the basis of their religious determination (religious identity). This paper advocates the opinion that such an effort for a complete integration of the identity of Macedonians independently of their religion is a good basis for upcoming development strategies and political strategies in the Republic of Macedonia.

\section{The Torbeshi autochthonous identity as "identity of resistance"}

The strategy for separating the Torbeshi as a separate ethno-religious community is especially interesting and important for the Macedonian history and survival. The most recent initiatives for constitutional proclamation of the Torbeshi as a separate nation (ethnos) in the Republic of Macedonia are a serious signa.l Firstly, they are a signal for the discontent of this part of the Macedonian nation from the governing policies of indifference toward their integration in society and its institutions. And secondly, they are a signal for the renewal of the propagandistic strategies and the strategies for systematic conversion and revision of the Macedonian identity (thereby the Macedonian people and nation, i.e. the Macedonian state). It's a matter of entwined, causative-consequential, interactive constellations and processes the Macedonian state and the Macedonian people are confronted with and the scientific thought should establish an opinion for them based on argumentative interpretations.

The initiative for declaring the "Macedonian Muslims" as a separate ethno-cultural community could be characterized as an attempt to legalize an "identity of resistance" with a tendency to transform it into a "legitimizing identity" - to use Manuel Castells' terminology from his book The Power of 
Identity (2002). The "identity of resistance" is motivated by several sociopolitical constellations of power distribution. These constellations spotlight the marginalization of one (religious, cultural, linguistic, ethnic) community, its stigmatization and its frequent ethnic redefining, which all lead to identity frustrations and confusions, i.e. to arbitrary interpretations of the minority identity, to manipulative power policies and to imagological stereotypes in regard to the stigmatized community (Mojsieva-Gusheva, 2014).

It seems that precisely the everyday political pragmatics in relation to the collective "awareness in development" for the genuine ethnic, cultural and religious identity of the Macedonians of Islamic religion, as well as the officialization of the multiethnic concept (multiculturalism) in the Republic of Macedonia, encouraged the initiatives for declaring one part of the Macedonian nation as a separate ethnic group. Namely, an initiative was announced in 2011 for the Torbeshi people to be proclaimed a legitimate constitutional ethnic community in the Republic of Macedonia as the third largest community in the state. This initiative was followed by adoption of the Charter of the identity of the Macedonian Torbeshi (Macedonians of Islamic religion) on a public convention held on 2 January 2011, as well as by publishing the Torbeshi Declaration written by Sherif Ajredinovski and issued by the newly established Torbeshi Cultural and Research Centre "Rumelia" in Struga in 2011.

The Torbeshi Declaration advocates the thesis for the autochthony and the uniqueness of the Torbeshi in a continuity of about ten centuries (from the $10^{\text {th }}$ century onwards). The declaration was later followed by the establishment of the Torbeshi Cultural and Research Centre "Rumelia" which became very active in the social media, as well as by an increased interest of the international cultural and scientific community for the "Torbeshi identity". Both the Declaration and the "Rumelia" Centre give certain argumentation in support of the requirement to constitutionally legalize the Torbeshi ethnicity. Besides the historical presence of the Torbeshi on the Balkans since the appearance of the Bogomil movement in Macedonia and in the wider Balkan region (10th century A.D.), beliefs about the uniqueness of the Torbeshi language, customs and ethno-cultural complex are also stated among the arguments. The declaration rejects the thesis that the Torbeshi are a part of the Macedonian nation which has converted from Christianity to Islam under the Ottoman Empire ${ }^{22}$. It starts

${ }^{22}$ The process of Islamisation of the Torbeshi population in Macedonia was, however, elaborately researched in Ottoman official documentation by the renowned ethnologist Galaba Palikrusheva in her $\mathrm{PhD}$ dissertation Islamisation of the Torbeshi and formation of the Torbeshi sub-group from 1965 (reissued in 2017). The historian Dragi Gjorgiev (whose special area of research is the Ottoman period and the translation of its census documents) 
from the conviction that the Torbeshi identity has a certain inherent heresy and that is the motive for their identification with the Bogomil heresy, which according to them is related to the Islamic religious and philosophical matrix.

This argumentation has a number of weaknesses: - the projection of the Islam in the Bogomil social, political and existential philosophy; - the Bogomils are members of a historically distinctive social movement and worldview with Gnostic and dualistic elements, not an autonomous ethnic group; - the Islamisation of the Macedonians and other Slavic nations on the Balkans (in this context also of the Torbeshi as well) took place at least one and a half century after the Ottoman conquest of the Balkans ${ }^{23}$; - there is no written evidence that the term "Torbeshi" dates from the $10^{\text {th }}$ century as a Slavic term for the "fudiagiagiti" and the "kudugeri" heretics (Bogomils); the Torbeshi language is Macedonian and contains ancient Slavic vernacular (Proto-Slavic/Common Slavic) and Old Church Slavonic words and its main developments and changes over several centuries of history (from the receiving of Islam onwards) are lexical by character. Namely, the numerous expressions associated with the Islamic pragmatics (rituals, customs, beliefs) have been incorporated in the language, but that is not sufficient to differentiate the Torbeshi language in Macedonia as different from the Macedonian language (Gajdova, 2011). Furthermore, today's research of the Gorani language on the territory of Kosovo and Serbia shows that the Gorani dialect is a part of the dialectal system of the Macedonian language (Drvoshanov, 2011; Antonova-Vasileva, 2014). ${ }^{24}$

\footnotetext{
substantiates the process in detail in many of his works. See, for instance, his latest paper "Islamisation in Macedonia in the Ottoman Empire" for the exact demographic numbers and explanations about when and how the process was slowly developing without organized Ottoman incentive, as well as about the methodology of research (2017, pp. 73-89).

${ }^{23}$ See Dragi Gjorgiev (2017).

${ }^{24}$ For an integral outlook on the dialectal system of the Slavic Macedonian language an interactive map of dialects is available on the website of the Research Centre for Areal Linguistics - ICAL (2018b) of the Macedonian Academy for Sciences and Arts. A schematic map in Macedonian, made by Marjan Markovikj and based on the works of Bozhidar Vidoevski, is available in Macedonian dialectology 2 (Markovikj, 2007, pp. 34-5). But, the most comprehensive map and brief analysis of the Macedonian dialects in English has been made by Victor A. Friedman in his paper "The Sociolinguistics of Literary Macedonian" (2015, pp. 185-212, “The Macedonian Dialects" section pp. 191-196, map on p. 188), and there is also an older, simpler map and refference grammar by him in an on-line dialectal webliography for students of Slavic languges (2001, p. 77). For classic, in-debth synchronous and diachronous analyses and maps of the Macedonian dialectal system in English see Bozhidar Vidoevski (2006). For an up-to-date account on the contemporary issues affecting the standard Macedonian language and all its dialects see Marjan Markovikj (2012).
} 
Actually, in the Declaration (as well as in other statements) Ajredinovski states that the most appropriate term to describe the identity of the Torbeshi is to say that they are Slavic Muslims, by which they declare that their origin is Slavic, and that the religion and the cultural features derived from the religious system they accepted are Muslim. ${ }^{25}$ It is interesting that today all religious-cultural communities with Slavic origin and Muslim religion in the Balkans (that means in Bulgaria, Macedonia, Serbia, Bosnia and Herzegovina and in Montenegro), almost unisonally identify themselves as Slavic peoples of Islamic religion and only additionally some linguistic and ethnographic features are derived as differential in regard to the native nation. But, despite the equal ethnic, linguistic and religious marker (Slavic and Islamic), so many names have been kept to designate these communities: (1) names with various imagological and cultural attributions of self-identification: Macedonians of Islamic religion, Macedonian Muslims, Torbeshi, Poturci/Turci, Pomaci/Pomaks (in the Rhodope part of Bulgaria), Islamised Estovci, Babushi and even the most general name "Nashinci" (literally translating as "Our People", ours vs. not ours) $)^{26}$; then (2) various local designations with the value of an ethnonym: Rekanci (from the Mala Reka and Golema Reka region), Debrani (from Debar), Drimkolci (from the Drimkol region, near Struga), Babuni (from the region around the river Babuna where the Bogomils acted!), Gorani (from the region Gora along the borders of today's Macedonia, Albania and Kosovo states) and Slaviano-Muslims, BulgarianMuslims and Slavic community with Islamic confession in Albania (Golo Brdo region, Dolno Poel or Peshkoi) ${ }^{27}$.

\section{The fluctuating identity of the Macedonians of Islamic religion}

The diversity of the local ethnonyms of the Macedonians of Islamic religion signal that their identity is in crisis, that the politics of their identity has lead to a crisis of their identity, which also reflects upon the notion of the wider Macedonian identity on a larger scale. The multi-decennial unstable political platform has destabilized the already fragile, convertive and fluctuating identity of the ethnic Macedonians of Islamic religion. ${ }^{28}$ The different ethnonyms of the Macedonians of Islamic religion are a real reflection of the heterogeneous historical tendencies in the identification and

25 The ethnographic research confirms the similarity between the folk costumes of the Macedonians and the Macedonians of Islamic religion (Mirchevska, 2011).

${ }^{26}$ See: A. A. Novik $(2009$, p. 75$)$.

${ }^{27}$ Rigels Halili (2013, p.488) gives the list of regions, cities and villages in the Republic of Albania with Macedonian ethnic minority.

28 Jolanta Sujecka (2013, p. 137-224) indicates how the adaptive identity of ethnic Macedonians reflects in the different 19 th century ethnonyms. 
the integration of this population within the official national and state systems. They testify to an instability in the perception of the dominant ethno-cultural marker in this population, as well as to the fact that they are a minority cultural-religious community and that they set themselves as identity of resistance or even heresy, but that still they have preserved their primary Slavic linguistic and cultural identity. Everything else is a matter of ephemeral civil, social and other policies.

The initiative of the Party for European Integration (PEI) and the Torbeshi Cultural \& Research Centre "Rumelia" in Struga originates from one both local and regional ethno-cultural and cultural-religious constellation, but is articulated in a given historical moment, mostly as a prolegomena to the multiethnic concept of the Republic of Macedonia and as an echo of the multicultural strategies and policies in the European and the international context. Precisely as a part of the broader geostrategic constellation (related to the countries of former Yugoslavia, but also to the concepts of the Balkans and Western Balkan), this initiative can also be read as a direct reflection of the constitutional amendments of 2001, especially the provision for a so-called Badinter majority or a right to veto based on the minority ethnic principle, supplemented by other law regulations and privileges (an "equitable" representation of the minority communities in the administration, the principle of so-called positive discrimination, etc.). ${ }^{29}$

Since the establishment of the Republic of Macedonia within the Yugoslav Federation (1944) to its independence (1991) and further on, to this present day, the Macedonians with Islamic religion underwent numerous revisions of their identity status. This is a type of "fluctuating identity" if observed from the perspective of denomination/determination in space and time. The multiplied identification and denomination of the Macedonians of Islamic religion seems to have appeared as a consequence of the accumulation of various imagological matrices by these Macedonians, given their additional (secondary) differences, primarily religious, and these religious differences supplemented by other sub-cultural traits and practices (worldview, religious rituals, moral code, modification of the inherited ethnographic symbols in clothing, homes, linguistic addressing, customs, etc.).

The fluctuating and dispersive identity of the Macedonian Muslims is also projected in the legal census classifications and identifications of the ethno-cultural, ethno-linguistic and ethno-religious structures and communities in the Republic of Macedonia. This community, which is de facto Macedonian, is classified in various ways in the columns of the demographic/population censuses: once under the column "Macedonians",

${ }^{29}$ There is no data that a similar provision has been legislated in any other country. 
but of Islamic religion, another time under the identity column "Albanians", but with Macedonian as mother tongue, third time as "Turks", but with Macedonian as mother tongue, then as "Bosniaks", but with Macedonian as mother tongue. ${ }^{30}$ This multiplied interpretation and perception of the identity of the Macedonian Muslims spreads to the neighboring countries, where, for example, in the Republic of Serbia, they define themselves as "Serbs" with Macedonian as mother tongue, and under the influence of Bulgarian cultural policies as "Bulgarians" by origin, with Bulgarian as mother tongue ${ }^{31}$.

The tendency of using the fluctuating identity (of resistance) of the Macedonians of Islamic religion for distinct ethno-political and strategic purposes leads to new, dramatic collective and personal traumas among the Macedonians of Islamic religion. It leads to new stigmas, migrations, conversions and alienations from the native Macedonian community. Unfortunately, down the long road of history it has already happened that parts of nations have given up their nationality or have been cut off from their native matrix and were incorporated in other nations and states, whether they migrated or the territory on which they lived was incorporated into another state. It has also happened that a part of some nation, over time and according to some historically acquired, cultural and religious specifics, does form a separate sense of self and declares themselves as a separate ethnic group, usually a minority. Hereby, decisive factors are not only the internal ethno-cultural markers, but also the broader social, political and state constellations, as well as the change in the theories of collective ethnic and national identities.

\section{Conclusion}

\section{The current situation of the Macedonians of Islamic religion}

The very act of opening the question of authenticity of identity raises a number of other sub-questions which are accompanied by internal divisions among the Macedonians of Islamic religion. Several years ago this act encouraged some political and scientific structures, in congruence with certain power structures, to seek solution for the status of the Macedonians of Islamic religion in the option for legalizing their identity. This instigated the Macedonians of Islamic religion, mainly from the Struga region, to demand (declaratively and through concrete political action) constitutional

\footnotetext{
${ }^{30}$ Ubavka Gajdova gives numerous examples of contemporary Macedonian settlements in western Macedonia with mixed ethnic and religious population where Macedonians of both religions speak the same language, thus giving indicators for their mutual ethnic identity regardless of their religious beliefs (2011, pp. 43-62).

${ }^{31}$ Ulf Brunbauer broadly discusses the attempts of the Bulgarian state politics to influence the change in the national identity of the Pomaks in Bulgaria (2002). Also Hugh Poulton (1997).
} 
legitimization of their religious-cultural identity as an ethnic one. Recent experiences with the role of the religious factor in determining identities in the wider Balkan region (in Bosnia and Herzegovina for instance) were also in favor of these options, as well as the geopolitical strategies regarding the Balkan region and, in a certain sense, regarding the "Macedonian question" in general.

Thus, over time, the community of Macedonians of Islamic religion has shown a tendency toward autonomy and ethnic self-awareness, especially highlighted in conditions of its neglect, marginalization and denial. This constellation has instigated a certain resistance among the Macedonians of Islamic religion toward the ruling constitutional, political and scientific classifications of the Macedonian identity pluralism and toward the Macedonian national centrism. Therefore, for the last 20 years a certain identity of resistance and a need for self-determination is generated among the Macedonians of Islamic religion, and with it a certain instability or variability of their ethnic status as well.

So, today we are faced with a certain contradiction: on one hand, the singularity of this religious-cultural community has not been large enough for it to separate itself from the Macedonian ethno-national entity and to counter the Macedonian identity, but on the other hand, it has articulated its specific features in the local environment, mostly the religious feature and its related cultural markers, due to the fact that the majority of the Macedonians were Orthodox Christians.

\section{Proposition for a possible solution}

\section{a) Inclusive state policies toward the entire Macedonian ethno-national entity regardless of religious affiliation}

Once the status of a cultural identity becomes a problem, the very identity is being questioned, even more so in the case of the subordinate and sub-ethnic identities, since they are mainly founded on partial cultural and religious markers, i.e. in their case correlativity and depending on the sociopolitical context is more emphasized. It should be emphasized that the radical movements for self-determination and secession of the Macedonians of Islamic religion from the total Macedonian ethno-national entity are overlooking the fact that the Macedonian identity is inclusive and is not exhausted with the generic and confessional affiliations, so it cannot be reduced to separate markers, whether they are religious or generic. As for the religious marker, it should be pointed out that the contemporary Macedonian identity allows unlimited religious freedom (theistic and atheistic), which influences a religious distinction among the Macedonians as Orthodox, Muslims, Catholics, Protestants, Evangelists, Jews, atheists and others. In other words, the Macedonian ethno-national identity, like any other 
established national identity, is a more general and more complex category than the religious. And the cultural identity of the Macedonians is layered and involves coexistence of multiple (derived) confessional, customary, moral, dialectal and gender otherness. ${ }^{32}$ So when talking about intercultural relations in the Macedonian state, the researcher does not mean only relations between Macedonians and other ethnic and linguistic communities, but also relations within the Macedonian ethno-national community.

This finding is supported by the fact that the processes of ethnic, religious and linguistic conversion of the Macedonians of Islamic religion intensified precisely from 1991 onwards (the period of independence of the Republic of Macedonia). There is a systematic multiplication of ethnic and religious otherness and its confirmation by the entire multiethnic, multireligious and multilingual establishment of the state. When policies of religious conversion were re-installed, the politicization of the religious institutions and identities was allowed. With such politicization, the manipulation (abuse) of religious identities and of religious people stepped onto the historical stage. In short, the radicalization of the religious diversity in the Republic of Macedonia is detrimental to the unity of the Macedonian people/nation, which negatively reflects upon the integrity, unity and imagological projection of the Macedonian state.

The official identification of the Macedonians of Islamic religion is a very sensitive issue because it entails a number of consequences for their linguistic and ethnic identity, but also for their existence and survival. Here are in brief only some of these systemic consequences: - cases of forcing Macedonian pupils with Macedonian mother tongue to study in Turkish and in Albanian language in primary schools have been registered; - cases of Macedonians declaring themselves as Turks or Albanians under various forms of coercion (by employing legal, political and other measures) have been registered; there have been dismissals of Macedonian language teachers in the areas inhabited by Macedonians of Islamic religion; ${ }^{33}$ - there has been an increased migration of Macedonians from religiously and

\footnotetext{
${ }^{32}$ The identity of the collective is multilayered, so one can talk about a multiple identity and about shared elements of the religious, ethnic and cultural identity (language, tradition, customs, rituals, ethnographic elements). One Macedonian can be Macedonian by birth, (from both parents' sides or from one parent's side in mixed marriages), by faith/religion a Macedonian may belong to various confessions, by language he/she should speak the Macedonian language, though this language may or may not be his/her mother tongue (regardless of the knowledge or use of other languages).

${ }^{33}$ With the Law on Secondary Education from 2002 (Assembley of the Republic of Macedonia, 11.07.2002) the found, existing demographic situation was revised, the structure of teachers was changed and there was a stimulation for migration of the Albanian population to the cities where the presence of the Albanian ethnic and linguistic factor was negligible.
} 
ethnically mixed areas, both of Orthodox Macedonians and of Macedonians of Islamic religion; - a negative imagology (stereotypes) of the Macedonian Muslims among the Macedonians themselves is being fueled...

At the beginning of the XXI century there is a more emphasized manifestation of the religious radicalisms on a local, regional and global level, so the Balkans is neither isolated nor resistant to such tendencies and policies. This kind of socially-political and developing environment makes the methodology of religious conversions current (again closely related to the ethnic conversions and identities), leaving immeasurable consequences on the migratory, demographic and geostrategic restructuring, i.e. on the inherited map of religious, ethnic and even state identities. This constellation on a regional and global level is also reflected upon the Macedonian conditions, so by lacking strategic analysis and preventive measures, the Republic of Macedonia may face serious disruption of the balance between the inherited, the existing and the new religious and ethnic identities, and through them of some elements of the state institutions.

In order to thwart the negative consequences, to thwart further disintegration of the Macedonian national entity and to give a civilized and humane reply to the attempts for secession of the Macedonian nation on ethnic principles, state measures are necessary: strategies for protection of the spiritual, linguistic and material heritage of the Macedonians of Islamic religion, strategies for interreligious communication between all Macedonians, policies on more appropriate social and institutional integration of the Macedonians of Islamic religion and a stimulation of educational, cultural, economic and developing policies. These strategies should also unveil and address the policies that generate social, communicational, economic, co-existential (co-habitative), religious and other reasons for marginalization and stigmatization of the community of Macedonians of Islamic religion in the Republic of Macedonia. The Macedonians of Islamic religion are a part of the Macedonian social, cultural and religious reality and should therefore be recognized as a specific cultural-religious community within the Macedonian nation and appropriate developing and integrative policies should be articulated for them. If stimulative development and integration policies continue to lack, it is not excluded that a secession of their identity may occur with a series of other consequences in relation to the entirety and integrity of the Macedonian nation and national institutions.

The self-determination of the individual and of the religious and cultural communities is not absolute, just as the official identification must not be rigid and insensible. Exclusion leads to disintegration and absurd social stratification, while the rational approach reconciles the extreme and radical interpretations of identity and creates conditions for deeper 
understanding and growth of the Macedonian nation, not only the Macedonian ethnicity.

\section{b) Inclusive civilizational strategies with inter-connective spiritual values: inter-religious palimpsests and symbiosis}

In the older ages of polytheism in the smaller ethnic and tribal communities by rule the religious identity was closely related to the ethnic identity. The monotheistic religions are oriented towards larger populations and towards various ethnic matrices, they are invasive and dominant, so they break the monolithic link between ethnicities and confession. The Eastern Roman (Byzantine) Empire made a turning point in the direction of constituting the nation as a supra-ethnic concept and confession as an interethnic category (as a form of a spiritually shared language of the different ethnicities). A similar thing happened in the Western Roman Empire. Since the 11th century on one side was the dominant role of Orthodox Christianity, and on the other side Catholic Christianity. Several centuries before, Christianity was undivided, a Christian union governed, established by suppressing the pagan polytheistic system. As the role of the Islamic confession strengthened, internal divisions and conversions occurred, so the state allowed simultaneous existence of both religious matrices, and also of other traditional and some new confessions.

As a rule, the Islamic religious matrix and practice in Macedonians were preceded by Christian ones. The Christian ones are older and furthermore, in the past, at the beginning of Islamisation, they were not suppressed mechanically and automatically, but they survived as a part of the spiritual heritage and tradition, so despite the new Islamic cults and customs, the older Christian ones were honored as well. ${ }^{34}$ Conversion is an act of replacing one religious code with another, renaming, Islamisation as Turkisation (which implies an ethnic dimension of the religious conversion), but it is achieved with a reserve, since the spiritual and collective memory is subtle, resistant and durable. Therefore it can also happen that an interreligious symbiosis is created on a more universal level, a spiritual religious palimpsest that strives for sublimation of the symbols and rituals of the past and of the current reality. So we often find metamorphoses or transformations of religious systems rather than the rigid replacement of one system with another. Sometimes the differences in the interpretation of

34 Mirjana P. Mirchevska explains concrete details of this in her case study on holiday celebrations by the Macedonian Muslim population from the Reka region (2009). And Dragi Gjorgiev mentions many examples of the syncretic faith practices by the Macedonians of Islamic religion from the Ottoman period: Christian hollidays celebrated by the populations of both faiths in mixed settlements, Christian icons with Muslim prayer inscriptions etc. (2017, pp. 87-89). 
religious doctrines are more drastic within one religion than between two religions.

The retrospective reflection on the past shows that behind every large religious, philosophical, ethical and ritual matrix there is some older one, until one reaches some of the ancient civilizations which were governed by the preconceptual worldview. Religion implies institutions and a political dimension. The pre-religious civilizations had a high sensitivity for nature and for harmony between the physical and the spiritual, between matter and energy, between the symbolic and the real. They were therefore more creative, more inventive and more free civilizations. The deeper one goes into the past and history, the closer one is to the archetypal patterns of the world and of harmony. Perhaps that is why today (in this researcher's opinion) we need to remind ourselves of these archetypal forms of humanity, love, goodness, justice and freedom, in order to prevent new civilizational and religious conflicts.

In this sense, the religious identity should not be a priority and the only legitimizing criterion of collective identities, nor should it be a key developing and geopolitical strategy. Religious radicalism is susceptible to manipulation and conflicts. It is not enough to declaratively emphasize the need for interreligious dialogue and coexistence in the media, but an integration of religious otherness in a more humane, more just and more free civilization is needed. Social development is more relaxed when religious practices are a part of the guaranteed human, personal and intimate rights, when the religious semiotics is more discrete and when an essential intercultural dialogue between people and communities is established. Today, in Macedonia (where many different religious and governing systems have changed through the centuries and where religions often transformed rather than denied one another), the map of religious diversity is also experienced as a form of a rich spiritual and cultural palimpsest that connects and remembers, instead of separating and forgetting.

\section{c) Iclusive state secular strategies}

And finally, the modern civilization must not marginalize the role of secularism, nor substitute statehood with church-religious institutions. The modern civilization is faced with a great temptation, to either continue with the deepening of religious schisms and with the increasing of the role of religious institutions and factors or to return to the positions of secular developing strategies. ${ }^{35}$ The scientific and unbiased minds of the world, as well as in the Republic of Macedonia, should remind us that secularism does

\footnotetext{
35 The researcher would like to reiterate that sometimes the differences in the interpretation of religious doctrines within one religion are more drastic than between two religions.
} 
not prohibit, nor abolish the right of religious affiliation. The secular philosophy protects the state, civil and national interests from religious atavisms and conflicts.

In this sense, it is good to perform rigorous scientific research for a comparative study of the cultural characteristics of the Macedonians of Islamic religion (and in that context of those who identify themselves as Torbeshi) through the official research institutions in the Republic of Macedonia. And there is a necessity for well-designed inclusive projects for social, educational, economic and political cohesion of the Macedonians regardless of their religious identity. The absence of secular strategies in the contemporary, independent Republic of Macedonia stimulates fragmentation of the Macedonian people, encourages new forms of ethnic, religious and linguistic conversions of Macedonians, increases migration movements, increases the emotional dimension of religious identity and, through it, of national identity, thereby stimulating the fluctuating moment in the identity not only of the Macedonians of Islamic religion, but even wider, of all the Macedonians who feel alienated in their homeland and rejected by the institutions of their country.

Religion should not be the exclusive factor of a collective identity like it was in the past (Ottoman or other). There is a need for less religious exclusivity and less political manipulation with ethnic communities (small and big). Less religiocentrisms would lead to less ethnocentrisms. More secularism would lead to less fragmentarism and balkanization.

Translated by Jasmina Ilievska-Marjanovic and Gala Kovachevic

Additional footnotes and bibliography by Jasmina Ilievska-Marjanovic Graphic adaptation of Map 1 by Andrej Marjanovic,

Map 2 by Marjan Markovikj - MANU

\section{References:}

1. Ajredinovski, Sherif. (2011). Torbeshka deklaracija. Struga: Torbeshki kulturno-nauchen centar/Torbeshi Cultural \& Research Centre "Rumelia" - Struga.

2. Anderson, Benedict. (1998). Zamisleni zaednici. Skopje: Kultura.

3. Anderson, Benedict. (2006, 1st. ed. 1983). Imagined Communities: Reflections on the Origin and Spread of Nationalism. London, New York: Verso. Available at: https://is.muni.cz/el/1423/podzim2013/SOC571E/um/Anderson_B__Imagined_Communities.pdf.

4. Antonova-Vasileva, Luchija. (2014). O govore dvuh obshtnoste musulmanskogo veroispovedanija: pomaki $\mathrm{v}$ Cheche i torbeshi $\mathrm{v}$ Go're. In Plotnikova, A. A., M. Ju. Martinova, E. S. Uzeneva (Eds.), Slavjane-musulmane na Balkanah: jezik, kultura, identichnost (pp. 
164-179). Moskva: Institut slavjanovedenija na RAN/Moscow: Institute for Slavic Studies of the Russian Academy of Sciences. Retrieved from http://inslav.ru/images/stories/pdf/2014_Slavjanemusuljmane.pdf

5. Arslani, Muhamed. (2011). Makedoncite so islamska religija se neotkinliv del od makedonskata nacija. In Makedoncite so islamska veroispoved - megju nacionalnata pripadnost $i$ religiskata opredelba (p. 72). Conference anthology of papers, the conference took place on 15.02.2011. Skopje: Sojuz na Makedoncite so islamska veroispoved Skopje/Macedonian Muslim Association - Skopje.

6. Assembly of the Republic of Macedonia/Sobranie na Republika Makedonija. Law on Secondary Education/Zakon za sredno obrazovanie. (11.07.2002). Official Gazette of the Republic of Macedonia/Sluzhben vesnik na Republika Makedonija, no. 52/02, as of 11.07.2002. Skopje: Official Gazzette of the Republic of Macedonia. Available at: http://www.slvesnik.com.mk/Issues/8CCCBA4B3DBC2342AA5175 457C4C9CC5.pdf

7. Bart, F. (2007). Etnichkite grupi i nivnite granici. In Lj. S. Risteski \& I. Jakimovska (Eds.), Drugosta vo etnologijata - Teorii na drugosta (pp.69-107). Skopje: Menora/Evrobalkan Press.

8. Brunbauer, Ulf. (2002). Dinamikata na etnichnosta: identitetot na Pomacite. In EtnoAntropoZum, No. 2 (pp. 1-18). Skopje: Institute of Ethnology and Anthropology. Retrieved from http://etno.pmf.ukim.mk/index.php/eaz/article/view/74/61

9. Castells, Manuel. (2009, $1^{\text {st }}$ ed. 1997). The Power of Identity. The Information Age: Economy, Society and Culture, Vol. II. Malden, MA, USA; Oxford, UK: Blackwell Publishing Ltd.

10. Cowan, Jane K. (2000). Macedonia: The Politics of Identity and Difference. London: PlutoPress.

11. Drvoshanov, Vasil. (2011). Dijalektnata leksika vo funkcija na makedonskiot jazik vrz primerot na rodninskata terminologija vo goranskiot govor. In Makedoncite so islamska veroispoved - megju nacionalnata pripadnost $i$ religiskata opredelba (pp. 73-90). Conference anthology of papers, the conference took place on 15.02.2011. Skopje: Sojuz na Makedoncite so islamska veroispoved Skopje/Macedonian Muslim Association - Skopje.

12. Friedman, Victor A. (2001). Macedonian. The SEELRC Refference Grammars. Durham, NC, USA: Duke University, Slavic and East European Language Resource Center (SEELRC), Duke University Slavic Centers. Available at: http://www.seelrc.org:8080/grammar/mainframe.jsp?nLanguageID=3 
13. Friedman, Victor A. (2015). Macedonian Studies 2. Skopje: Macedonian Academy of Sciences and Arts. Available at: http://ical.manu.edu.mk/books/FriedmanMacStudies2.pdf

14. Friedman, Victor A. (2017). Languages of the Balkans. Oxford: Historical Linguistics, Language Families/Areas/Contact. Retrieved from:

http://linguistics.oxfordre.com/view/10.1093/acrefore/978019938465 5.001.0001/acrefore-9780199384655-e-348

15. Gajdova, Ubavka. (2011). Mestoto na jazikot na Makedoncite so islamska veroispoved vo makedonskiot dijalekten kompleks. In Makedoncite so islamska veroispoved - megju nacionalnata pripadnost $i$ religiskata opredelba (pp. 43-62). Conference anthology of papers, the conference took place on 15.02.2011.Skopje: Sojuz na Makedoncite so islamska veroispoved - Skopje/Macedonian Muslim Association - Skopje.

16. Gjorgiev, Dragi. (2017). Islamizacijata vo Makedonija vo Osmanliskiot period (Islamisation in Macedonia in the Ottoman Empire). In Contributions XLVII, 2 [Volume dedicated to acad. Ivan Katardzhiev]. Skopje: Macedonian Academy for Sciences and Arts, Section for Social Sciences. Retrieved from: http://manu.edu.mk/wpcontent/uploads/2017/03/Opshtestveni-1.pdf

17. Guibernau, Montserrat. (2004). Anthony D. Smith on nations and national identity: a critical assessment. Nations and Nationalism 10 (1/2) (pp. 125-141). London: ASEN. Retrieved from: https://pdfs.semanticscholar.org/293a/8dabdfaa7c1cbd9667eaad2662 d6875fe1f5.pdf

18. Halili, Rigels. (2013). Macedonians in Albania - from ethnic group to national minority. In Jolanta Sujecka (ed.), Colloquia Balkanica, vol. 2 [Macedonia: Land, Region, Borderland], (pp. 483-506). Warsaw: Faculty of „Artes Liberales“, University of Warsaw.

19. Krause, Todd B. and Jonathan Slocum. (2003). Old Church Slavonic Online: Series Introduction. Early Indo-European Online. Austin, TX: Linguistics Research Centre at the College of Liberal Arts, University of Texas. Available at: https://web.archive.org/web/20090917003440/http://www.utexas.edu /cola/centers/lrc/eieol/ocsol-0-X.html

20. Koleva, Krasimira. (2014). Homo slavicus \& homo balcanicus Problemi identichnosti v epohu globalizacii (situacija Kosovo). In Plotnikova, A. A., M. Ju. Martinova, E. S. Uzeneva (Eds.), Slavjanemusulmane na Balkanah: jezik, kultura, identichnost (pp. 97-116). Moskva: Institut slavjanovedenija na RAN/Moscow: Institute for 
Slavic Studies of the Russian Academy of Sciences. Retrieved from http://inslav.ru/images/stories/pdf/2014_Slavjane-musuljmane.pdf.

21. Makarcev, Maksim M. (2014). Jazik slavjan-musulman Elbasana: postanovka voprosa. In Plotnikova, A. A., M. Ju. Martinova, E. S. Uzeneva (Eds.), Slavjane-musulmane na Balkanah: jezik, kultura, identichnost, (pp. 197-214).

22. Markovikj, Marjan, ed. (based on works by Bozhidar Vidoevski). (2007). Dijalektologija na makedonskiot jazik 2. Skopje: Filoloshki fakultet „Blazhe Koneski“" Skopje.

23. Markovikj, Marjan. (2012). Macedonian Language from the Perspective of its Balkan Environment (Language Tendencies). In Jolanta Sujecka and Maciej Falski (Eds.), Colloquia Humanistica 1: The Continuity and Discontinuity as a Research Problem, (pp. 8196). Warszawa: Institute of Slavic Studies, Polish Academy of Science. Retrieved from: https://ispan.waw.pl/journals/index.php/ch/article/view/ch.2012.006/ 35

24. Mirchevska, Mirjana P. (2007). Verbalni i neverbalni etnichki simboli vo Gorna Reka, volume 2. Skopje: Institut za etnologija i antropologija, posebni izdanija.

25. Mirchevska, Mirjana P. (2009). Holiday Celebration Of The Population Of Gorna Reka Related To Folk Religion. In: EtnoAnthropoZum, No. 6 (pp.191-215). Skopje: Institute of Ethnology and Anthropology. Retrieved from: http://etno.pmf.ukim.mk/index.php/eaz/article/view/222/197

26. Mirchevska, Mirjana P. (2011). Javno manifestiranje na drugiot kulturen identitet - oblekata na Makedonkite muslimanki (torbeshki) od makedonsko-albanskiot granichen prostor. In Makedoncite so islamska veroispoved - megju nacionalnata pripadnost i religiskata opredelba (pp. 9-24). Conference anthology of papers, the conference took place on 15.02.2011. Skopje: Sojuz na Makedoncite so islamska veroispoved - Skopje/Macedonian Muslim Association - Skopje.

27. Mirchevska, Mirjana P. (2014). Sovremennie konstrukcii identitchnosti na primere Makedoncev-musulman. In Plotnikova, A. A., M. Ju. Martinova, E. S. Uzeneva (Eds.), Slavjane-musulmane na Balkanah: jezik, kultura, identichnost, (pp. 117-133). Moskva: Institut slavjanovedenija na RAN/Moscow: Institute for Slavic Studies of the Russian Academy of Sciences. Retrieved from http://inslav.ru/images/stories/pdf/2014_Slavjane-musuljmane.pdf

28. Mojsieva-Gusheva, Jasmina. (2014). Ulogata na identitetot na balkanskiot prostor. Conference paper, the conference on the subject of Balkan Identities was held in Skopje, November 2014. Skopje: 
Macedonian Academy of Sciences and Arts (MASA) and Bulgarian Academy of Sciences (BAS).

29. Novik, A. A. (2009). Transformacii v samosoznanii Makedoncevmusulman v Albanii: materiali ekspedicii 2008 g. In Perehodi. Peremeni. Prevrashtenija. Balkanskie Chtenija 10. Tezisi i materiali, (pp. 74-78). Moskva: Institut slavjanovedenija na RAN \& Centar lingvokulturnih isledovanija „Balcanica“/Moscow: Institute for Slavic Studies of the Russian Academy of Sciences \& Centre for Linguocultural Researches „Balcanica“. Available at: http://inslav.ru/images/stories/pdf/2009_Balkanskie\%20chtenija_10_ Perexody_Peremeny_Prevraschenija.pdf

30. OLA (General Slavic Linguistic Atlas) Commission of the International Congress of Slavists. (2018). General Slavic Linguistic Atlas publications. Description data on project and publications available at: http://ola.zrc-sazu.si/OLF-publikacije.htm, http://ola.zrcsazu.si/OLB15ENG-uvod.htm, http://slavatlas.org/ and http://slavatlas.org/publications.html. Macedonian dialects general overview and map available at: http://ola.zrc-sazu.si/OLAVSE/FO_1981_823--831_SADRZAJ,_KARTA.pdf http://slavatlas.org/geo.html.

31. Palikrusheva, Galaba. (2017, first ed.1965). Islamizacijata na Torbeshite $i$ formiranje na torbeshkata subgrupa. $\mathrm{PhD}$ dissertation. Skopje: Institut za etnologija i antropologija / Institute of Ethnology and Anthropology.

32. Plotnikova, A. A., M. Ju. Martinova, E. S. Uzeneva, Eds. Slavjanemusulmane na Balkanah: jezik, kultura, identichnost. Moskva: Institut slavjanovedenija na RAN/Moscow: Institute for Slavic Studies of the Russian Academy of Sciences. Available at http://inslav.ru/images/stories/pdf/2014_Slavjane-musuljmane.pdf.

33. Poulton, Hugh. (1997). Changing Notions of National Identity among Muslims in Trace and Macedonia: Turks, Pomaks and Roma. In Hugh Poulton and SuhaTaji-Farouki (Eds.), Muslim Identity and the Balkan State, (pp. 82-102). London: Hurst \& Company, in association with the Islamic Council.Poulton, Hugh. (2000). Who are the Macedonians? London: C. Hurst and Co. Publishers.

34. Research Centre for Areal Linguistics of the Macedonian Academy for Arts and Sciences (ICAL, MANU). (2018a). On-line resources available at: http://ical.manu.edu.mk/

35. Research Centre for Aerial Linguistics of the Macedonian Academy for Sciences and Arts (ICAL, MANU). (2018b). Dialect Texts (Map). Skopje: ICAL, MANU. Available at: http://ical.manu.edu.mk/Map/Map.html. 
36. Research Centre for Aerial Linguistics of the Macedonian Academy for Sciences and Arts (ICAL, MANU). (2018c). Digital Archive of the Macedonian Language. Skopje: ICAL, MANU. Available at: http://damj.manu.edu.mk/index_en.html

37. Ribarova, Zdenka (Ed.). (2000). Rechnik na crkovnoslovenskiot jazik od makedonskata redakcija, vol.1 (Dictionary of the Macedonian Recension of Church Slavonic). Skopje: Institut za makedonski jazik "Krste Misirkov" (Macedonian Language Institute).

38. Ribarova, Zdenka. (2005). Jazikot na makedonskite crkovnoslovenski tekstovi (The Language of the Macedonian Church Slavonic Texts). Skopje: Macedonian Academy of Sciences and Arts.

39. Sharevski, Mario. (2015). Geografskata razmestenost i etnografskite odliki na Makedoncite muslimani vo Makedonija. MASA Scientific conference "Macedonian Muslims in contemporary and historical context", 29.06.2015. Skopje: KOVZ, MANU. Retrieved from: https://www.academia.edu/17512111/\%D0\%93\%D0\%95\%D0\%9E\% D0\%93\%D0\%A0\%D0\%90\%D0\%A4\%D0\%A1\%D0\%9A\%D0\%90 $\%$ D0\%A2\%D0\%90\%D0\%A0\%D0\%90\%D0\%97\%D0\%9C\%D0\%9 5\%D0\%A1\%D0\%A2\%D0\%95\%D0\%9D\%D0\%9E\%D0\%A1\%D0\% A2_\%D0\%98 \%D0\%95\%D0\%A2\%D0\%9D\%D0\%9E\%D0\%93\%D 0\%A0\%D0\%90\%D0\%A4\%D0\%A1\%D0\%9A\%D0\%98\%D0\%A2\% D0\%95 \%D0\%9E\%D0\%94\%D0\%9B\%D0\%98\%D0\%9A\%D0\%98 $\%$ D0\%9D\%D0\%90_\%D0\%9C\%D0\%90\%D0\%9A\%D0\%95\%D0\%9 4\%D0\%9E\%D0\%9D\%D0\%A6\%D0\%98\%D0\%A2\%D0\%95_\%D0\% 9C\%D0\%A3\%D0\%A1\%D0\%9B\%D0\%98\%D0\%9C\%D0\%90\%D0 \%9D\%D0\%98 \%D0\%92\%D0\%9E \%D0\%9C\%D0\%90\%D0\%9A\% D0\%95\%D0\%94\%D0\%9E\%D0\%9D\%D0\%98\%D0\%88\%D0\%90

40. State Statistical Office of the Republic of Macedonia (MAKSTAT). (2002). Census of Population: Households and dwellings in the Republic of Macedonia, 2002 - Book X. Skopje: MAKSTAT. Available at: http://www.stat.gov.mk/Publikacii/knigaX.pdf

41. State Statistical Office of the Republic of Macedonia (MAKSTAT). (2017). Macedonia in Figures, 2017. Skopje: MAKSTAT. Retrieved at: http://www.stat.gov.mk/Publikacii/MakBrojki2017_en.pdf

42. Sujecka, Jolanta. (2012). Profile of Rafael Kamhi \& Macedonian Borders (original text in ladino: Las Fronteras de Macedonia). In Jolanta Sujecka \& Maciej Falski (Eds.), Colloquia Humanistica [The Continuity and Discontinuity as a Research Problem], (pp. 273-280). Warsaw: Institute of Slavic Studies/Polish Academy of Sciences.

43. Sujecka, Jolanta. (2013). The Image of Macedonia and the categories rod - narod - natsiya in literature from Macedonia in the 19th and the first half of the 20th century. In Jolanta Sujecka (Ed.), Colloquia 
Balkanica, vol. 2 [Macedonia: Land, Region, Borderland], (pp. 137234). Warsaw: Faculty of „Artes Liberales“, University of Warsaw.

44. Svetieva, Aneta. (1992). Sovremenata sostojba na shopskata etnichka zaednica vo Kratovo i Krivopalanechko. In Etnologija, No.1, Zbornik na Muzejot na Makedonija/Museum of Macedonia Reader (pp. 9-18). Skopje: Muzej na Makedonija/Museum of Macedonia.

45. Svetieva, Aneta. (2004). Politicization of the ethnic identity of the Torbesh (the "Nashinci"). In EtnoAntropoZum, No. 4 (pp. 49-69). Skopje: Institute of Ethnology and Anthropology. Retrieved from http://etno.pmf.ukim.mk/index.php/eaz/article/view/264/239

46. Toncheva, Veselka. (2013). The Slavonic Community from the Golo Bardo Region, Republic of Albania: Traditions, Music, Identity. In Our Europe. Ethnography - Ethnology - Anthropology of Culture, vol. 2, (pp. 39-55). Poznan: The Poznan Society for the Advancement of Arts and Sciences. Retrieved from http://www.ptpn.poznan.pl/Wydawnictwo/czasopisma/our/OE-2013039-056-Toncheva.pdf

47. Toncheva, Veselka. (2014). Tradicionnie pesni iz oblasti Goloborda (Golloborde). In Plotnikova, A. A., M. Ju. Martinova, E. S. Uzeneva (Eds.), Slavjane-musulmane na Balkanah: jezik, kultura, identichnost, (pp. 268-295). Moskva: Institut slavjanovedenija na RAN/Moscow: Institute for Slavic Studies of the Russian Academy of Sciences. from http://inslav.ru/images/stories/pdf/2014_Slavjane-musuljmane.pdf

48. Toncheva, Veselka. (2016). Bulgarite ot Golo Burdo, Albania. Chast III. Sofia: Rod.

49. Vidoevski, Bozhidar. (1998). Govorite na islamiziranite Makedonci vo Zapadna Makedonija. Dialects of Macedonian Language, vol.1. Skopje: Macedonian Academy of Sciences and Arts. Retrieved from: http://dijalekti.manu.edu.mk/pdf/\%D0\%B4\%D0\%B8\%D1\%98\%D0 \%B0\%D0\%BB\%D0\%B5\%D0\%BA\%D1\%82\%D0\%B8\%20\%D0\%B D\%D0\%B0\% 20\%D0\%BC\%D0\%B0\%D0\%BA.\%20\%D1\%98\%D0 \%B0\%D0\%B7\%D0\%B8\%D0\%BA\% $20 \% \mathrm{D} 1 \% 82 \% \mathrm{D} 0 \% \mathrm{BE} \% \mathrm{D} 0 \% \mathrm{~B}$ C1.pdf

50. Vidoevski, Bozhidar. (2006). Dialects of Macedonian. Indiana University: Slavica Publishers. 